\title{
Cover crops in the upper midwestern United States: Potential adoption and reduction of nitrate leaching in the Mississippi River Basin
}

\author{
E.J. Kladivko, T.C. Kaspar, D.B. Jaynes, R.W. Malone, J. Singer, X.K. Morin, and T. Searchinger
}

\begin{abstract}
Nitrate $\left(\mathrm{NO}_{3}\right)$ losses from agricultural lands in the Midwest flow into the Mississippi River Basin (MRB) and contribute significantly to hypoxia in the Gulf of Mexico. Previous work has shown that cover crops can reduce loadings, but adoption rates are low, and the potential impact if cover crops were widely adopted is currently unknown. This paper provides an analysis of potential cover crop adoption and relative benefits to water quality across the five-state region of Ohio, Indiana, Illinois, Iowa, and Minnesota in the upper midwestern MRB. Two agricultural counties were selected in each of the five states, and the potential for fall-planted cover crop adoption was estimated based on cash crop rotation and tillage systems. In these 10 counties, an estimated $34 \%$ to $81 \%$ of the agricultural land could have cover crops integrated into their corn (Zea mays L.) and soybean (Glycine max L.) cropping systems. These adoption rates would in some cases require shifts of current tillage practices from fall to spring, but could be even higher with increased adoption of no-till and mulch-till. Nitrate reduction simulated with the Root Zone Water Quality Model for the tile drained portion of the corn-soybean and continuous corn cropping systems in the five-state area, under the assumed management systems and uniform soil properties, showed that cover crops have the potential to reduce $\mathrm{NO}_{3}$ loadings to the Mississippi River by approximately $20 \%$. These predictions suggest that cover crop adoption would have a beneficial impact on water quality in the MRB and would contribute greatly towards meeting the national goal of significant reduction in $\mathrm{NO}_{3}$-nitrogen $(\mathrm{N})$ load entering the Gulf.
\end{abstract}

Key words: adoption — cover crops - hypoxia-Mississippi River — nitrate leaching — water quality

Nitrate (NO) in surface waters of the Mississippi River Basin (MRB) degrades freshwater quality in the region and much of it is eventually transported to the Gulf of Mexico where it contributes to hypoxia (Rabalais et al. 1996). Agricultural land devoted to corn (Zea mays L.) and soybean (Glycine max L.) production in the Upper Midwest makes a major contribution to $\mathrm{NO}_{3}$ found in surface waters (Burkart and James 1999; Goolsby et al. 2001; David et al. 2010). Alexander et al. (2008) estimated that over $50 \%$ of the nitrogen $(\mathrm{N})$ fluxes from the Mississippi River originated from agricultural land producing corn and soybean. In addition, artificial drainage systems used primarily for corn and soybean production increase losses of $\mathrm{NO}_{3}$ from agricultural land (Goolsby et al. 2001; Royer et al. 2006) by accelerating transport to surface water
(Zucker and Brown 1998) and bypassing subsurface flow paths that would reduce $\mathrm{NO}_{3}$ concentrations through denitrification or other processes (Schilling et al. 2007). As a result, five upper midwestern states (Iowa, Illinois, Indiana, Ohio, and Minnesota), which have large areas of artificially drained land used for corn and soybean production, contribute about $46 \%$ of the $\mathrm{NO}_{3}-\mathrm{N}$ load to the Mississippi River that reaches the Gulf of Mexico (Alexander et al. 2008; Robertson et al. 2009).

Significant leaching losses of $\mathrm{NO}_{3}$ can occur in corn and soybean cropping systems during the late fall, winter, and early spring, in part because living plants are not removing water and $\mathrm{NO}_{3}$ from soil during this time. Fall-planted winter cover crops reduce annual leaching losses of $\mathrm{NO}_{3}$ because they extend active $\mathrm{NO}_{3}$ and water uptake into this fallow period of the year. Research has clearly shown that cover crops can substantially reduce $\mathrm{NO}_{3}$ losses in tile drainage in corn and soybean systems in the Upper Midwest (Kaspar et al. 2012, 2008, 2007; Strock et al. 2004; Kladivko et al. 2004). Field studies from across the United States have estimated reductions in $\mathrm{NO}_{3}$ leaching losses with cereal grain cover crops ranging from 13\% to $94 \%$ (table 1). In a meta-analysis of 69 studies from around the world using direct and indirect measurements, Tonitto et al. (2006) calculated that nonleguminous cover crops reduced leaching losses of $\mathrm{NO}_{3}-\mathrm{N}$ by an average of $70 \%$. In general, the amount of $\mathrm{N}$ uptake and transpiration by cover crops and the subsequent reduction in $\mathrm{NO}_{3}$ leaching losses relate directly to the amount of cover crop growth. Cover crop reductions of $\mathrm{NO}_{3}$ leaching, however, also are affected by amount and intensity of precipitation, amount of drainage, soil type, and cropping system management. In most research studies, cover crops have been grown on the entire area measured for $\mathrm{NO}_{3}$ losses. In a typical agricultural watershed, however, it is unlikely that cover crops will be implemented by farmers on all the available land area, and as result their effect on $\mathrm{NO}_{3}$ losses within a watershed will be proportionally reduced.

The first challenge for cover crop adoption in corn and soybean cropping systems in the Upper Midwest is successful seeding and establishment of the cover crop in fall. In general, cover crops, like winter rye (Secale cereal L.), that are usually winter hardy need to emerge and grow to a minimum size to achieve their best winter hardiness, winter survival, and growth in the spring (Clark 2007). If cash crop harvest is early enough, drilling or broadcasting with shallow incorporation after harvest are the most reliable seeding methods for cover crops. For a particular location, however, the timing of

Eileen J. Kladivko is a professor in the Department of Agronomy at Purdue University in West Lafayette, Indiana. Tom C. Kaspar, Dan B. Jaynes, Rob W. Malone, and Jeremy Singer are research scientists with the USDA Agricultural Research Service National Laboratory for Agriculture and the Environment in Ames, lowa. Xenia K. Morin is an associate dean in the School of Environmental and Biological Sciences at Rutgers, The State University of New Jersey in New Brunswick, New Jersey. Timothy Searchinger is an associate research scholar at the Woodrow Wilson School in Princeton University in Princeton, New Jersey. 


\section{Table 1}

Literature summary of percent reduction in nitrate-nitrogen $\left(\mathrm{NO}_{3}-\mathrm{N}\right)$ leaching losses due to cereal cover crops.

\begin{tabular}{llll}
\hline Cover crop & $\begin{array}{l}\text { Reduction } \\
\text { in No-N } \\
\text { leaching (\%) }\end{array}$ & $\begin{array}{l}\text { Location } \\
\text { (in the } \\
\text { United States) }\end{array}$ & Reference \\
\hline Oats & 81 & Alabama & Jones 1942 \\
Oats & 26 & lowa & Kaspar et al. 2012 \\
Rye & 77 & Maryland & Staver and Brinsfield 1990 \\
Rye & 94 & Kentucky & McCracken et al. 1994 \\
Rye & 65 to 70 & California & Wyland et al. 1996 \\
Rye & 32 to 42 & Oregon & Brandi-Dohrn et al. 1997 \\
Rye & 30 & Delaware & Ritter et al. 1998 \\
Rye & 80 & Maryland & Staver and Brinsfield 1998 \\
Rye & 28 to 68 & Michigan & Rasse et al. 2000 \\
Rye & 13 & Minnesota & Strock et al. 2004 \\
Rye & 61 & lowa & Kaspar et al. 2007 \\
Rye & 48 & lowa & Kaspar et al. 2012 \\
Winter wheat + less & 61 & Indiana & Kladivko et al. 2004 \\
fertilizer & & & \\
\hline
\end{tabular}

harvest and postharvest cover crop planting is very dependent on the weather and cash crop management in a particular year, and the normal harvest date of corn and soybean at a particular location. Full season corn and soybean crops grown for grain often are harvested relatively late in some years and this may not leave much time for fall cover crop growth before average hard frost dates and freezing of the soil surface. Winter cereal rye used as a cover crop can normally be drilled until late October throughout most of the five-state region. However, in Minnesota and northern Iowa, hard frosts and freezing of the surface soil in late October and early November would limit establishment, fall growth, and winter survival of even winter rye (Midwest Cover Crops Council 2012). As a result, drilling or planting cover crops after late corn and soybean grain harvest in these areas sometimes does not result in good establishment and winter survival or much cover crop growth and $\mathrm{N}$ uptake (Feyereisen et al. 2006).

Overseeding or aerial seeding into a standing crop of corn or soybean just before or at maturity allows cover crops to be seeded much earlier than drilling after grain harvest, but it is usually less effective than planting with a drill on the same date (Fisher et al. 2011). Overseeding is typically done by a custom application from aircraft, but can also be done by broadcast seeding with groundbased, high clearance equipment. Unless soil water is readily available and rains have been occurring frequently, overseeding works best if delayed until about the time of corn or soy- bean maturity, which is when the main crop stops using water and begins to shed leaves. Cover crop establishment using overseeding at maturity, however, is still dependent on precipitation after seeding (Wilson et al. 2013), which tends to be highly variable in fall in the Midwest. Shading by the drying cash crop before harvest or by the residue after harvest can also limit cover crop growth and small cover crop plants can be damaged during harvest by wheel traffic. Winter cereal cover crops, however, seem to tolerate shading and harvest wheel traffic relatively well (Clark 2007). In general, with experience and timely rain overseeding can be used to successfully establish winter rye cover crops early enough to allow sufficient time for fall growth throughout the corn-soybean production areas of the five-state region. Thus, between drilling after harvest or overseeding before harvest a winter rye cover crop can usually be successfully established in corn and soybean cropping systems throughout most of the five-state region.

Although the harvest or maturity date of the previous crop determines when cover crops can be established, the tillage system is also important. Any type of tillage reduces the time available for cover crop growth. In general, cover crops are easier to integrate into no-till and strip-till systems (or other partial-width tillage systems) compared with full-width tilled systems because they allow earlier planting in the fall and more time for cover crop growth in the spring before terminating them with herbicides. Cover crops also provide synergistic benefits to no-till or strip-till systems because cover crop roots can help to alleviate compaction and poor soil structure-sometimes associated with these systems - through the addition of organic matter and the penetration of compacted soil by cover crop roots (Kaspar and Singer 2011). When full-width tillage is used in a cropping system, spring tillage makes use of cover crops far easier than fall tillage. Many types of spring tillage can be compatible with cover crops, but particularly so if farmers delay spring tillage until just before planting the cash crop. For some soil types or for some cash crops, however, delaying tillage until just before planting is not desirable, especially if the tillage is used to dry out and warm the soils. Alternately, fall full-width tillage after harvest would either delay the planting of the cover crop or would terminate a cover crop overseeded into the cash crop at maturity or planted after a short-season cash crop. If additional labor is available, fields that are already harvested could be tilled and planted with cover crops even while harvest continued on other unharvested fields. In any case, although it is possible to incorporate cover crops into systems with fall tillage, especially in the southern part of the five-state region, it is much more difficult and leaves less time for cover crop growth.

Five upper midwestern states (Iowa Illinois, Indiana, Ohio, and Minnesota) that are dominated by corn and soybean production (NASS 2009) contribute nearly half of the $\mathrm{NO}_{3}-\mathrm{N}$ load delivered by the Mississippi River to the Gulf of Mexico (Alexander et al. 2008; Robertson et al. 2009). For cover crops to significantly reduce $\mathrm{N}$ loads to the Gulf of Mexico, they must be integrated into corn and soybean production systems in these five states. This paper analyzes the potential for cover crop adoption in corn and soybean cropping systems based on crop rotations and tillage systems for 10 counties in critical watersheds across the five-state region. Then using the same assumptions on potential cover crop adoption; databases for crop rotation, tillage, and agricultural land with artificial drainage systems; and the modeling scenarios for cover crop reductions of $\mathrm{NO}_{3}$ losses using a uniform soil type described by Malone et al. (2014 [this issue]), we estimate the potential water quality benefits on land with artificial drainage across the five-state region for two scenarios of cover crop adoption. 


\section{Materials and Methods}

Simplifying Cover Crop Selection. Although there are many potential cover crop species, for simplicity we conducted this analysis of relative benefit and potential adoption of cover crops using only winter cereal rye. Singer (2008) in a survey of midwestern farmers found that cereal rye was the most commonly used cover crops species. Additionally, Kaspar et al. (2007, 2012) used cereal rye in their Iowa studies on the effect of cover crops on $\mathrm{NO}_{3}$ losses to tile drainage, and Li et al. (2008) and Malone et al. (2014) used a winter cereal rye cover crop in their modeling simulations. In general, winter rye is the most cold tolerant of all potential cover crop species, is winter hardy across the entire five-state region, will tolerate moderate frosts, and will grow at temperatures down to $1^{\circ} \mathrm{C}$ $\left(34^{\circ} \mathrm{F}\right)$ (Clark 2007). Therefore, it is reasonable to simplify our analysis by using winter cereal rye for the winter-hardy cover crop.

Estimating Crops and Crop Rotations. For counties throughout the five-state region we used National Agriculture Statistics Service (NASS) satellite-derived cropland estimates for 2008 and 2009 (CropScape) (NASS 2011) to estimate percentages of total agricultural land used to produce corn, soybean, or wheat (Triticum aestivum L.), and the rotations used involving those crops. These spatial databases were loaded into a geographic information system (GIS) (ArcGIS version 9.3.1, ESRI, Inc., Redlands, California), and the $30 \mathrm{~m}(98.4 \mathrm{ft})$ resolution cropland data were resampled into 1 ha (2.47 ac) cells spanning the five states for 2008 and 2009. Each 1 ha $(2.47 \mathrm{ac})$ cell was assigned with the majority crop, vegetation, or miscellaneous land cover designation identified within the 1 ha $(2.47 \mathrm{ac})$ area. Crop land area estimates were based on 2009 data, and crop rotations were based on the crops in each 1 ha $(2.47 \mathrm{ac})$ cell in both 2008 and 2009. County or state level data were calculated by resampling the 1 ha $(2.47 \mathrm{ac})$ cells using county and state boundaries. There is some error associated with this process with misidentification of crops or land cover, averaging within cells, or cells that cross field boundaries. Additionally, the same problems are compounded when applied across two years to determine rotations with the additional problem of slight misalignment errors between cells derived from satellite photos taken a year apart. Some of these errors average out for cropland area within a single year, but for rotation data there are some reductions in land area for individual rotations that are not recovered because of misalignment or misidentification and are subsequently classified as an incorrect rotation category or unidentified. Additionally, because we are focusing on corn and soybean in rotation with corn, soybean, or wheat, land area that was not planted in corn or soybean in 2009 and not planted in corn, soybean, or wheat in 2008 , or on which the crop was destroyed by weather events in either of the two years, would not show up in the corn or soybean rotation data.

Estimating Tillage Systems. Tillage data for the targeted counties were obtained from a 2004 tillage survey (CTIC 2011), which is the most recent available covering all five states. Tillage data were collected in spring after planting of the cash crop. Thus, the tillage system identified for a particular crop refers to tillage operations and soil disturbance occurring after harvest of the previous crop and through planting of the current crop. The Conservation Technology Information Center (CTIC) survey defined no-till, strip-till, and ridge-till as tillage systems that had disturbed to varying degrees less than one-third of the surface area of the field through planting. Mulch-till was defined as full-width tillage that disturbed $100 \%$ of the soil surface, but left greater than $30 \%$ residue cover after planting. Reduced tillage systems were defined as full-width tillage systems that left between 15\% and $30 \%$ surface residue cover after planting. Lastly, conventional or intensive tillage was defined as full-width tillage leaving less than $15 \%$ residue cover after planting. The CTIC database gives the land area of corn and soybean in no-till, ridge-till, mulch-till, reduced-till, and conventional tillage for each county within a state. It does not, however, list tillage practice by crop rotation. Although we realize that some farmers do use no-till with continuous corn, we assumed that $100 \%$ of the no-till and ridge-till land areas in corn were in a corn-soybean rotation rather than in continuous corn because the planting and stand establishment problems caused by high crop residue levels in continuous corn would likely discourage many farmers from using no-till or ridge-till for this rotation. We then assumed that the fraction of the remaining tillage practices were proportionally higher in continuous corn. Similarly, the relative fractions of corn land area in the other tillage systems for the corn-soybean rotation were decreased proportionally to accommodate the increased no-till and ridge-till land area.

Estimating Extent of Drained Land. To estimate the impact of a fall-planted rye cover crop on the total $\mathrm{NO}_{3}$ load leaving artificially drained fields and entering surface waters each year, we needed to estimate the extent of drained land used to produce corn and soybean in the five states. Unfortunately, no current estimate of the extent of drained soils exists. The last Census of Drainage to collect systematic drainage information was more than 30 years ago in 1978. In 1982, and again in 1992, the National Resources Inventory (NRI) conducted by the Natural Resource Conservation Service (NRCS) (2011) collected drainage information, but no field data have been collected and released since then. In 1987, Pavelis (1987) used land capability class and crop information collected in the 1982 NRI to estimate the extent of drained cropland. These estimates were published for selected states in the 1987 USDA publication Farm Drainage in the United States.

Given that installation of additional drainage systems has continued since these data were collected, we elected to use a method similar to Jaynes and James (2007) for estimating the extent of drained lands. We assumed that soils with properties that require artificial drainage for good crop production must be drained if they are currently being used for crop production. We identified the location of soils requiring drainage by using the NRCS State Soil Geographic Database soils database (STATSGO) (Soil Survey Staff 2012). The STATSGO database has since been updated to STATSGO2 by NRCS. We used the STATSGO database to compute the fraction of every STATSGO map unit requiring artificial drainage based on the fractional composition of the soils making up the mapping unit and the properties of each soil. Jaynes and James (2007) found that soils with a land capability class of II, III, or IV and with a wet limitation $(w)$ best identified soils needing drainage. We used the same procedure in this study. To identify the fraction of the soils needing artificial drainage also being used for crop production, we followed the procedure of Jaynes and James (2007). This procedure used the 1992 National Land Cover Database (NLCD) developed by the US Geological Survey and US Environmental Protection 
Agency (USGS 2011) to determine which crops were being grown on the soils. Jaynes and James (2007) used the NLCD classification for row crops (82), small grains (83), and fallow (84) to identify drained lands. In this study, we only used the NLCD classification for row crops (82) to quantify the extent of soils requiring drainage that are in corn or soybean production. Overlaying the STATSGO and NLCD spatial databases, we estimated the area of corn and soybean land benefitting from artificial drainage.

Criteria for Cover Crop Adoption. The CTIC tillage data did not distinguish between fall and spring primary tillage. The season of tillage, however, greatly affects the ease with which cover crops can be integrated into the system. As discussed earlier, full-width fall tillage either delays planting of fall cover crops or terminates overseeded cover crops prematurely and in general makes management of cover crops extremely difficult. We assumed that it would be unlikely that cover crops would be used in cropping systems with full-width fall tillage or in systems that would be unlikely to be converted from fall tillage to spring tillage or no-till. Thus, to determine all feasible cropping systems with potential for cover crop adoption we made the following assumptions:

(1) If the previous crop was corn and residue cover after planting is less than 30\% (classified as reduced-till or conventional-till), then because of the normally high residue levels following corn, it is likely that fall tillage and multiple tillage passes occurred to reduce residue cover levels below $30 \%$. Additionally, in many parts of the five-state region fall tillage following corn is a common practice and usually still leaves enough residues to protect the soil over winter. Thus, for reduced or conventional-till following corn before either soybean or corn we assumed that fall tillage occurred and cover crops could not be integrated into this system.

(2) If the previous crop was soybean and residue cover after planting is less than $30 \%$, then either fall or spring tillage may have occurred. Because of the rapid decomposition and low levels of soybean residues, even a single aggressive full-width tillage pass in the spring often will reduce residue levels below $30 \%$. Thus, farmers often are reluc- tant to till soybean residues in the fall because there are not enough residues to protect the soil over winter and residue levels can be reduced quickly in the spring with one full-width tillage pass. Conversely, if farmers are presently using full-width tillage in the fall following soybean, they could convert relatively easily to a one-pass full-width spring tillage system, fall or spring strip-till, or no-till (Vetsch et al. 2007). As a result, we assume that following soybean before either corn or soybean, that if tillage does occur it could be done in the spring and cover crops could be integrated with all tillage systems following soybean.

(3) If the previous crop is either corn or soybean and mulch tillage is being used, we assume that tillage is either already being done in the spring or that it can be converted from fall to spring tillage. Thus, cover crops could be used with mulch-till in all rotations.

(4) If the previous crop was wheat, we assume that tillage system does not affect cover crop use because the early harvest of wheat in late July or early August allows plenty of time for cover crop growth in the fall, even if fall tillage is used.

(5) If no-till is being used in a corn-soybean rotation, then cover crops could be used. To simplify discussions, we have combined no-till and ridgetill together as NT and combined reduced tillage and conventional tillage together as red/conv.

Analysis of Potential for Cover Crop Adoption in 10 Counties. To begin to analyze the potential magnitude of cover crop adoption and its effect on $\mathrm{NO}_{3}$ leaching losses in the Upper Midwest region, we first estimated maximum potential adoption of a winter rye cover crop in corn and soybean cropping systems in 10 Mississippi River Basin Initiative (MRBI) watersheds (NRCS 2012.), two in each of the five states. These watersheds represent a range of cropping systems and climatic conditions yet all make significant contributions to $\mathrm{NO}_{3}-\mathrm{N}$ loads to the Mississippi River and Gulf of Mexico (Robertson et al. 2009). Additionally, these MRBI watersheds have been selected by NRCS to demonstrate how cropping and conservation practices can affect watershed $\mathrm{NO}_{3}$ levels (NRCS 2012.). One represen- tative agricultural county in each of the 10 MRBI watersheds was chosen, and we obtained county-level data on cropping systems and rotations for 2008 and 2009 (NASS 2009) and tillage practices from a 2004 survey (CTIC 2011). Using these data and the criteria described above, we estimated the percentage of agricultural land on which cover crops could be implemented. Because corn and soybeans represented more than $85 \%$ of the total annual row crop land in all of the 10 watersheds (NASS 2009), our analysis focused mostly on those crops and wheat.

Analysis of the Reduction of Nitrate Losses by Cover Crops. Malone et al. (2014 [this issue]) used Root Zone Water Quality (RZWQM)-Decision Support System for Agrotechnology Transfer (DSSAT) to examine the effect of a cereal rye cover crop on $\mathrm{NO}_{3}$ leaching on artificially drained lands at 41 locations across the Upper Midwest. Their analysis focused on simulating the relative impact of rye across the region resulting from regional differences in weather, $\mathrm{N}$ fertilizer application rates, and main crop differences (cultivar and planting/harvest dates). Their modeling analysis assumed a uniform set of soil properties across the artificially drained soils in the region, similar to the modeling analysis of Thorp et al. (2008) for evaluating drainage water management across the Midwest. Similarly, Feyereisen et al. (2013) and Baker and Griffis (2009) modeled rye cover crop growth across the region, using regional weather data, but also assuming uniform soil properties. Although assuming uniform soil properties across the region is a simplification, we would expect that restricting our analysis to soils requiring artificial drainage would reduce the variation among soils. Additionally, Kaspar et al. (2007, 2008, and 2012) and Tonitto et al. (2006), have previously concluded that the amount of $\mathrm{N}$ uptake and subsequent reduction of $\mathrm{N}$ leaching losses by cover crops are strongly related to the amount of cover crop growth and the volume of water percolating through the soil profile, both of which are predominantly affected by weather conditions. Presently, there is not a suitable mechanistic agricultural systems model available that has been calibrated for the range of soils on subsurface drained cropland across the region (Thorp et al.2008). Thus, to use a modeling approach to examine how the reduction of $\mathrm{NO}_{3}$ leaching by cover crops is affected by soil properties would require a separate, extensive effort at 
some later date and is beyond the scope of our paper.

Malone et al. (2014 [this issue]) simulated rotations of corn-soybean or corn-corn with either no-till or spring tillage. Continuous corn and corn-soybean rotations represented $77 \%$ of all the land area used for corn and soybean production in 2009. Corn and soybean grown in other crop rotations were not included in the regional analysis because there are a large number of possibilities, each of which would have to be simulated explicitly with RZWQM. Additionally, as explained earlier, some land area with corn and soybean production was not included because of averaging within the cells, a destroyed crop, prevented planting, or possible misidentification of crops in one of the two years.

For the regional analysis, we examined two scenarios or combinations of rotations and tillage systems. For both scenarios, only artificially drained land was considered. For scenario 1 , we conservatively assumed that a winter rye cover crop would only be used in fields with a corn-soybean rotation and either no-till or ridge-till systems. For these fields, we used RZWQM to simulate the reductions in $\mathrm{NO}_{3}$ losses resulting from overseeding winter rye cover crops at corn or soybean maturity. Although overseeding is not as reliable for establishing a cover crop as drilling (Fisher et al. 2011), with experience success of this practice usually improves, according to Eileen Kladivko (personal communication, October 30, 2013).

For scenario 2, we increased the potential land area of cover crop adoption by including the continuous corn rotation and those rotation and tillage system combinations that could be accomplished with full-width spring tillage. This is similar to the criteria for cover crop adoption used for the case studies, but is limited to continuous corn and corn in rotation with soybean and does not include continuous soybean or rotations with wheat. For this scenario, we used RZWQM estimates of $\mathrm{NO}_{3}$ reduction on tile drained land for overseeding a winter rye cover crop at maturity into either corn-soybean or corn-corn rotations and in either a spring full-width tillage system or a no-till system as appropriate.

The RZWQM simulation results for the reduction of $\mathrm{NO}_{3}$ leaching by a winter rye cover crop for 41 sites across the Upper Midwest for the scenarios discussed by Malone et al. (2014) were imported into ArcGIS (Version 9.3.1; ESRI, Inc., Redlands, California) and were interpolated across the five-state region. This spatial information was then combined with the spatial databases for drained lands, prevalence of corn-soybean rotation, and different tillage systems to compute the county average $\mathrm{NO}_{3}$ reduction possible with winter rye. To estimate the loss of $\mathrm{NO}_{3}$ across the five states for these two scenarios, we used the appropriate RZWQM modeling estimates for the reduction of $\mathrm{NO}_{3}$ leaching to tile drains from the incorporation of winter rye into the cropping system. The simulated change in $\mathrm{NO}_{3}$ loss per hectare was multiplied by the land area in each county that was estimated as drained and used for corn and soybean production. This product was multiplied by the appropriate fraction of corn being grown in rotation with either soybean or corn estimated from the 2008 and 2009 NASS cropland databases to match the rotations used in the modeling. This fraction was then multiplied by the fraction of either corn or soybean in the appropriate tillage system from the CTIC data. Finally the reductions from the different production systems included in the various scenarios were summed to give the total change in $\mathrm{NO}_{3}-\mathrm{N}$ mass entering surface waters for each county in the five states.All results were imported into ArcGIS version 9.3.1 (ESRI, Inc., Redlands, California), manipulated as discussed above, and portrayed within the GIS.

\section{Results and Discussion}

Estimates for Cover Crop Adoption in Clinton County, Indiana: Illustration of Case Study Calculations and Assumptions.

This section presents our estimates for the potential for cover crop adoption on agricultural land growing corn, soybean, or wheat in Clinton County, Indiana. Clinton County is located in the Wildcat Watershed in northern Indiana. Details are provided below to illustrate the methods, data sources, calculations, and assumptions used. Table 2 presents data and calculations for Clinton County, Indiana, and table 3 presents results for all 10 counties analyzed.

To calculate the percentage of a county's agricultural land likely to adopt cover crops, we focused on corn, soybean, and wheat crops, and only the rotations and tillage practices associated with corn and soybean production. In any case, NASS CropScape data from 2009 for Clinton County, Indiana had 43,527 ha $(107,560 \mathrm{ac})$ of corn, 39,352 ha $(97,243 \mathrm{ac})$ of soybeans, and $712 \mathrm{ha}(1,758$ ac) of wheat (NASS 2011) or as percentages of agricultural land, $49.8 \%$ corn, $45 \%$ soybean, and $0.8 \%$ wheat (table 2). Similarly, CropScape data from 2009 and 2008 were used to determine rotations of corn and soybean with corn, soybean, or wheat. For the most part soybean followed corn, with smaller percentages of soybean following soybean or wheat. The sum of the three soybean rotations was $43.1 \%$, which indicates $1.9 \%$ of the agricultural land in 2009 was soybean following no crop, another crop, or could not be determined. Corn in Clinton County mostly followed soybean, with $12.3 \%$ of agricultural land with corn following corn and a small percentage of corn following wheat. As with soybean, $1.8 \%$ of the agricultural land was corn following no crop, another crop, or not determined.

For tillage systems (table 2), soybean fields were surveyed at $63 \%$ no-till, $13 \%$ mulchtill, and $24 \% \mathrm{red} / \mathrm{conv}$, and these percentages were applied equally across soybean following corn and soybean following soybean. For corn the CTIC survey data showed $4 \%$ NT, $2 \%$ mulch-till, and $94 \%$ red/conv. Because we assumed that there was zero no-till in continuous corn and that all no-till corn fields were corn following soybean, the percentages were proportionally adjusted as shown in table 2. We assumed that for corn or soybean following wheat the tillage system did not matter because wheat is harvested early enough that even with full-width fall tillage there would have been enough time for substantial cover crop growth to occur.

Crop rotation-tillage combinations (table 2) were calculated by multiplying the crop rotation percentage (table 2) by the grouped tillage system percentage (table 2). For example, $37.6 \%$ of the agricultural land was soybean after corn multiplied by $63 \%$ of soybean land area that was classified as no-till to obtain $(37.6 \% \times 63 \%) 23.7 \%$ of agricultural land in the county was NT soybean. It would have been easy to integrate cover crops into these fields, because it is easy to aerial seed winter rye cover crops into standing corn before the soybean. Therefore all land area in this category could have provided water quality benefits through inclusion of cover crops.

Working through the other soybean after corn and tillage system combinations, 4.9\% and $9 \%$ of the county's agricultural lands are soybean after corn in mulch tillage and 


\section{Table 2}

Case study analysis for Clinton County, Indiana, in the Wildcat Watershed.

\begin{tabular}{|c|c|c|c|c|c|c|c|}
\hline Crop & $\begin{array}{l}\text { County's } \\
\text { agricultural } \\
\text { land in } \\
\text { each crop } \\
(\%)\end{array}$ & Rotation & $\begin{array}{l}\text { County's } \\
\text { agricultural } \\
\text { land in } \\
\text { each rotation } \\
\text { (\%) }\end{array}$ & Tillage system & $\begin{array}{l}\text { Distribution } \\
\text { of tillage } \\
\text { system } \\
\text { within crop } \\
\text { and rotation (\%) }\end{array}$ & $\begin{array}{l}\text { County's } \\
\text { agricultural } \\
\text { land in a } \\
\text { crop rotation- } \\
\text { tillage } \\
\text { combination } \\
(\%)^{*}\end{array}$ & $\begin{array}{l}\text { County's } \\
\text { agricultural } \\
\text { land } \\
\text { with } \\
\text { potential } \\
\text { for cover } \\
\text { crops (\%) } \\
\end{array}$ \\
\hline \multirow[t]{5}{*}{ Soybean (S) } & 45.0 & S after $C$ & 37.6 & No-till & 63 & 23.7 & 23.7 \\
\hline & & S after $S$ & 5.2 & No-till & 63 & 3.3 & 3.3 \\
\hline & & & & Mulch & 13 & 0.7 & 0.7 \\
\hline & & & & Reduced/conventional & 24 & 1.2 & 1.2 \\
\hline & & S after W & 0.3 & All & 100 & 0.3 & 0.3 \\
\hline \multirow[t]{4}{*}{ Corn (C) } & 49.8 & C after S & 34.8 & No-till & 5.4 & 1.9 & 1.9 \\
\hline & & & & Mulch & 2.0 & 0.2 & 0.2 \\
\hline & & & & Reduced/conventional & 97.9 & 12.0 & 0.0 \\
\hline & & C after W & 0.9 & All & 100 & 0.9 & 0.9 \\
\hline Wheat (W) & 0.8 & All & 0.8 & All & 100 & 0.8 & 0.0 \\
\hline Sum & & & 91.9 & & & 91.9 & 70.0 \\
\hline
\end{tabular}

*Calculated by multiplying the land in each rotation by the distribution of tillage system within crop rotation.

$\mathrm{red} / \mathrm{conv}$ tillage systems, respectively. As described earlier, we assume that all mulch tillage operations could be performed in the spring, and thus, cover crops can be included in this tillage-rotation combination. Conversely, we assume that red/conv tillage systems following corn usually indicate fall tillage, and therefore cover crops would not be included in this tillage-rotation combination (table 2). Soybean after soybean is planted on only $5.2 \%$ of the county's agricultural land, and because tillage of soybean residue can be delayed to spring, we assumed that cover crops could be applied to all tillage systems and land area in this rotation.

Corn following soybean occupied 34.8\% of the county land area. Multiplying 34.8\% by the sum of $5.4 \%$ (corn in NT) and $2 \%$ (corn in mulch-till) gave a total of $2.6 \%$ of the county's agricultural land as no-till or mulch-till corn after soybean. Because it would have been easy to aerially seed a winter rye cover crop into the standing soybean crop or to drill rye after soybean harvest, these acres were counted in our potential cover crop land area calculations. We are also assuming that any mulch-till would have occurred in spring, which because of the normally low levels of residue following soybean is a relatively common practice. Similarly, corn after soybean rotations with red/conv tillage were planted on $32.2 \%$ of the county's agricultural land. Production systems with corn after soybean and red/conv tillage often use a one-pass fullwidth spring tillage operation, and this would have allowed cover crop integration, especially with aerial seeding into standing soybeans. On the other hand, some of these farmers might also be convinced to convert to no-till or strip-till before corn, with proper technical assistance and equipment setup, which would provide more time for cover crop growth and more choices of cover crop species.

Corn after corn (continuous corn) was calculated as $12.3 \%$ of the county's agricultural land, and only the small area $(0.2 \%)$ in mulch-till continuous corn would have had the potential for including cover crops. We assumed that there was no corn after corn no-till and that land area in corn after corn was proportionally distributed between mulch-till and red/conv tillage systems. As with soybean after corn, we assumed that the $\mathrm{red} / \mathrm{conv}$ land area after corn is usually tilled in the fall, making it very difficult to include cover crops. Thus, we assumed no cover crops on $(97.9 \% \times 12.3 \%) 12 \%$ of the agricultural land in the county (table 2 ).

We assumed that cover crops could be grown on land area with soybean after wheat or corn after wheat rotations regardless of tillage systems. Because of the additional time for cover crop growth following wheat harvest in July or early August, it is easy to include cover crops in these rotations. There are a wide variety of cover crop species that could be grown on these acres due to the early harvest date of wheat. Additionally, many of the wheat acres in this county receive manure (manure is applied to 2.5\% of the county acres [NASS 2009]), and as a result cover crops would have a potentially larger impact.

Although wheat (mostly after soybean) was grown as a cash crop on $0.8 \%$ of the agricultural land, this land area was not considered to have a potential for winter cover crops preceding wheat. This was done because the cash crop wheat (usually winter wheat) is growing during the same time period as a winter cover crop and although it provides the same benefit in terms of reducing $\mathrm{N}$ leaching losses, it is not considered a cover crop in this situation. However, we would assume that if more acres were converted from the current corn-soybean rotation to rotations including wheat, then some of the same benefits of cover crops would be realized during the wheat cash crop year and cover crops would also be easy to establish and effective after the wheat.

Estimates of Cover Crop Adoption for All 10 Counties. Using the same calculations as 
Table 3

Final results from case study analyses of 10 midwestern counties.

\begin{tabular}{|c|c|c|c|c|c|c|}
\hline \multirow[b]{2}{*}{$\begin{array}{l}\text { State-county- } \\
\text { watershed }\end{array}$} & \multirow[b]{2}{*}{$\begin{array}{l}\text { Agricultural } \\
\text { land with } \\
\text { potential } \\
\text { for cover } \\
\text { crops }(\%)\end{array}$} & \multirow[b]{2}{*}{$\begin{array}{l}\text { Agricultural } \\
\text { land in } \\
\text { continuous } \\
\text { corn }(\%) \\
\end{array}$} & \multicolumn{3}{|c|}{ Limiting factors for cover crop adoption } & \multirow[b]{2}{*}{ Comment } \\
\hline & & & $\begin{array}{l}\text { Agricultural } \\
\text { land not } \\
\text { in corn or } \\
\text { soybean } \\
\text { production (\%) }\end{array}$ & $\begin{array}{l}\text { Agricultural } \\
\text { land that is } \\
\text { corn or } \\
\text { soybean } \\
\text { following other } \\
\text { crops or no } \\
\text { crop (\%) }\end{array}$ & $\begin{array}{l}\text { Agricultural } \\
\text { land with } \\
\text { reduced or } \\
\text { conventional } \\
\text { tillage following } \\
\text { corn; assumed } \\
\text { to be fall } \\
\text { tillage (\%)* }\end{array}$ & \\
\hline $\begin{array}{l}\text { Indiana-Clinton } \\
\text { County-Wildcat }\end{array}$ & 70.0 & 12.3 & 5.2 & 3.8 & 21.1 & $\begin{array}{l}\text { Fall tillage is the biggest } \\
\text { limiting factor; } 0.8 \% \text { wheat. }\end{array}$ \\
\hline $\begin{array}{l}\text { Indiana-Decatur } \\
\text { County-Upper } \\
\text { East Fork White }\end{array}$ & 59.2 & 8.3 & 18.6 & 9.7 & 12.5 & $\begin{array}{l}\text { Combination of all three } \\
\text { limiting factors; large } \\
\text { percentage not in corn or } \\
\text { soybean production; } \\
1 \% \text { wheat. }\end{array}$ \\
\hline $\begin{array}{l}\text { lowa-Wright } \\
\text { County-Boone }\end{array}$ & 80.9 & 16.0 & 4.1 & 3.1 & 12.0 & $\begin{array}{l}\text { Mostly corn and soybean; fall } \\
\text { tillage only significant limiting } \\
\text { factor. }\end{array}$ \\
\hline $\begin{array}{l}\text { lowa-Calhoun } \\
\text { County-North } \\
\text { Raccoon }\end{array}$ & 70.7 & 17.0 & 6.4 & 6.3 & 16.6 & $\begin{array}{l}\text { Same as other lowa county; } \\
\text { fall tillage primary limiting } \\
\text { factor. }\end{array}$ \\
\hline $\begin{array}{l}\text { Ohio-Darke } \\
\text { County-Upper } \\
\text { Great Miami }\end{array}$ & 65.7 & 4.2 & 18.8 & 7.2 & 8.3 & $\begin{array}{l}\text { Relatively high percentage } \\
\text { with crops or uses other than } \\
\text { corn or soybean; } 5.7 \% \text { wheat. }\end{array}$ \\
\hline $\begin{array}{l}\text { Ohio-Delaware } \\
\text { County-Upper } \\
\text { Scioto }\end{array}$ & 47.7 & 1.2 & 40.5 & 4.7 & 7.2 & $\begin{array}{l}\text { Very high percentage of crops } \\
\text { or uses other than corn or } \\
\text { soybean; } 5.1 \% \text { wheat. }\end{array}$ \\
\hline $\begin{array}{l}\text { Illinois-Grundy } \\
\text { County-Upper } \\
\text { Illinois }\end{array}$ & 62.6 & 21.0 & 3.0 & 4.8 & 29.5 & $\begin{array}{l}\text { Mostly corn and soybean; } \\
\text { primary limiting factor is fall } \\
\text { tillage after corn. }\end{array}$ \\
\hline $\begin{array}{l}\text { Illinois-Vermilion } \\
\text { County-Vermillion }\end{array}$ & 60.2 & 12.0 & 7.1 & 5.5 & 27.2 & $\begin{array}{l}\text { Mostly corn and soybean; } \\
\text { primary limiting factor is fall } \\
\text { tillage after corn. }\end{array}$ \\
\hline $\begin{array}{l}\text { Minnesota-Nicollet } \\
\text { County-Middle } \\
\text { Minnesota }\end{array}$ & 45.8 & 20.0 & 10.7 & 4.4 & 39.1 & $\begin{array}{l}\text { Mostly corn and soybean; } \\
\text { primary limiting factor is fall } \\
\text { tillage after corn. }\end{array}$ \\
\hline $\begin{array}{l}\text { Minnesota- } \\
\text { Fillmore } \\
\text { County-Root }\end{array}$ & 34.4 & 13.0 & 40.3 & 10.5 & 14.7 & $\begin{array}{l}\text { Very high percentage of crops } \\
\text { or uses other than corn and } \\
\text { soybean; some fall tillage } \\
\text { after corn. }\end{array}$ \\
\hline
\end{tabular}

* Sum of soybean after corn and corn after corn in reduced/conventional tillage, as illustrated in table 2.

detailed for Clinton County, Indiana, in table 2 , potential cover crop adoption was estimated for all 10 counties and is presented in the first column of table 3. Potential cover crop adoption rates in corn and soybean rotations for the 10 counties from critical MRB watersheds ranged from $45.8 \%$ to $80.9 \%$ based on different distributions of crop rotation and tillage systems (table 3). Three counties had less than $48 \%$ of their agricultural land considered feasible for cover crops in this analysis. Nicollet County, Minnesota, had almost no NT or mulch-till corn and had about $20 \%$ continuous corn. As a result, this county had almost $40 \%$ of its agricultural land with reduced or conventional tillage following corn, which is assumed to include fall tillage, as discussed earlier. Additionally, over $10 \%$ of the county's agricultural land was not in corn or soybean production and was not included in our analysis of potential cover crop adoption. Fillmore County in Minnesota had more no-till or mulch-till compared with Nicollet County, but still had
$14.7 \%$ reduced or conventional tillage following corn. It also was one of two counties in which greater than $40 \%$ of the agricultural land was not used to produce corn, soybean, or wheat. Much of this land area was harvested as forage and although the forage acres are not counted in cover crop acres, they may have similar or greater environmental benefits. Delaware County in Ohio was the other county that had over $40 \%$ of its agricultural land in crops or uses other than corn and soybean production, $5.1 \%$ of which was 
wheat. Thus, these three counties had limited potential for cover crop adoption in corn and soybean rotations due to the high percentage of conventional or reduced tillage after corn and because of land area in forage, pasture, or other crops, which may or may not have potential for cover crops.

Both Illinois and Indiana counties, and one county in Ohio had about $60 \%$ or more of their agricultural land rated as feasible for cover crops. Both Illinois counties and Clinton County in Indiana had less than 7\% of their agricultural land used for crops or uses other than corn and soybean. Clinton County also had relatively high NT soybean. Fall tillage resulting from reduced or conventional tillage following corn was the primary factor limiting cover crop adoption in these three counties. Darke County in Ohio and Decatur County in Indiana both had 18\% of their land area in crops or uses other than corn or soybean production, and $7 \%$ to $10 \%$ of their corn and soybean crops followed fallow, unidentified land use, or crops other than corn, soybean, or wheat, which were not considered in the analysis. Thus, our estimates of adoption of cover crops in corn and soybean rotations were limited primarily by fall tillage for three of the counties and primarily by land use and nonstandard rotations in the other two counties.

Two counties in Iowa, Wright County and Calhoun County, had $80.9 \%$ and $70.7 \%$ of their agricultural land, respectively, deemed feasible for cover crops in corn and soybean rotations. This is primarily because $94 \%$ to $96 \%$ of the agricultural land in these counties is used to produce corn and soybean. Additionally, these two counties had $29 \%$ to $33 \%$ mulch-till soybean after corn. In some cases to adopt cover crops the farmers using mulch-till would either need to change from fall to spring mulch-till or would need to convert from mulch-till to no-till. In general, the main limiting factor to cover crop adoption in these counties is fall tillage after corn.

In general, these estimates show that the potential for adoption of cover crops in these critical MRBI watersheds is substantial and that cover crops should be considered as one of the primary conservation practices to improve water quality in these watersheds.

Model Simulations of Potential Cover Crop Reductions in Nitrate Losses. The estimates of the potential of winter rye cover crops to reduce the losses of $\mathrm{NO}_{3}$ over the five-state region and in the 10 selected counties are based on the RZWQM simulations of Malone et al. (2014 [this issue]). These simulations considered only artificially drained lands and the corn-soybean or corncorn rotations with either no-till or spring tillage because the model has only been tested and validated for artificially drained corn and soybean systems with a winter rye cover crop and because artificial drains discharge directly into surface waters. Modeling the fate of $\mathrm{N}$ leaching from nonartificially drained lands was beyond the scope of our objectives. Obviously, although corn and soybeans are the predominant crops in these five states, winter rye cover crops could be included with corn and soybean in rotation with other crops (for example following wheat or continuous soybean). Additionally, cover crops could be used in corn and soybean systems that are not artificially drained. Even in systems without artificial drainage, we would expect that a winter rye cover crop would reduce the amount of $\mathrm{NO}_{3}$ leached to the bottom of the root zone. Depending on the soils, terrain, hydrology, and geology of a given site, water and $\mathrm{NO}_{3}$ at the bottom of the root zone is partitioned into various flow paths. Some of this water and $\mathrm{NO}_{3}$ would move downward to local groundwater and some would follow subsurface lateral flow paths and eventually enter surface waters (Tomer and Burkart 2003; Schilling et al. 2007). Along both of these pathways some of the $\mathrm{NO}_{3}$ in the water would be lost through denitrification and other processes (Schilling et al. 2007). We hypothesize that on fields that are not artificially drained, cover crops would probably reduce the amount of $\mathrm{NO}_{3}$ reaching surface waters, but the percentage reductions attributable only to cover crops may be less than that of tiled drained land. Thus, using the restrictions imposed by the model for rotations and to artificially drained land, we believe that the model assessments are somewhat conservative.

The fraction of all row crop land across the five-state region estimated to be artificially drained row crop is shown in figure 1a. The use of artificial drainage in row crop production is wide spread across western Ohio, north and central Indiana and Illinois, and central Iowa into southcentral Minnesota, extending through the Red River Valley of northwestern Minnesota. However, much of the drained area in northwestern Ohio and the Red River Valley of northwestern
Minnesota lie outside of the Mississippi drainage area and do not contribute nutrients to the Gulf. Figure 1b shows the area by county that was in a corn-soybean rotation in 2008 and 2009. This crop rotation was very common across the five Midwest states except in eastern Ohio and northeastern Minnesota. Shown in figure $1 \mathrm{c}$ is the distribution of land used to grow corn after corn in 2008 and 2009. This rotation was concentrated in northern and central Illinois, the northern two thirds of Iowa, and southern Minnesota, and little used in Ohio, southern Indiana, and southern Illinois. Corn and soybean also were grown in rotation with wheat or other crops as discussed in the ten counties used as case studies, but in most cases this is relatively small percentage of corn and soybean production area.

The RZWQM simulation results from Malone et al. (2014 [this issue]) were interpolated across the five-state region and then were combined with the spatial databases for drained lands, corn-soybean rotations, and different tillage systems to compute the county average $\mathrm{NO}_{3}$ reduction possible with a winter rye cover crop. Figure $2 \mathrm{a}$ shows the total county reduction in $\mathrm{NO}_{3}$ losses for scenario 1, which is for tile drainage lands when the winter rye cover crop is overseeded into no till corn-soybean cropping systems at maturity. It is clear from this figure that most of the benefit is in the area stretching from western Ohio to east central Illinois. The predicted winter rye effect is less in northern Iowa and Minnesota despite the predominance of row crop production on tile-drained soils because no-till is rare in these areas.

A winter cover crop had an even greater extent of simulated benefits across the five states when the potential land area of cover crop adoption was increased for scenario 2 by adding the continuous corn rotation and those rotation and tillage system combinations that could be accomplished with full-width spring tillage. There is a marked increase in potential $\mathrm{NO}_{3}$ loss reductions in Iowa, southern Minnesota, central Illinois and Indiana, and western Ohio (figure 2b). This increase results primarily from two assumptions that increased the area of potential cover crop adoption. First, we assumed that all mulch-till after corn or soybean was either performed in the spring or could have been converted to spring tillage. Second, we assumed that all red/conv tillage after soy- 


\section{Figure 1}

For five midwestern states the (a) fraction of all land in each county that is drained row crops, (b) area in each county that was in a corn-soybean rotation in 2008 and 2009, and (c) area in each county that was in a corn after corn rotation in 2008 and 2009.

(a)

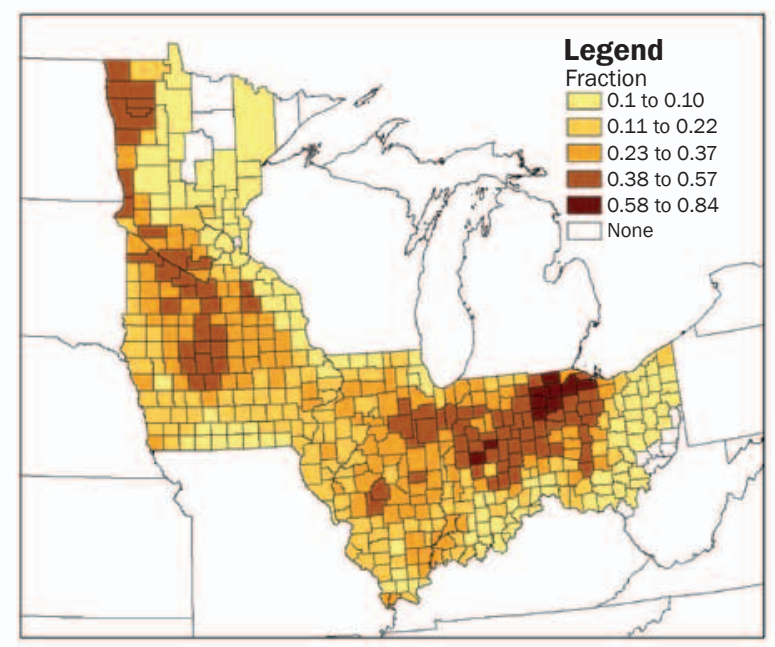

(b)

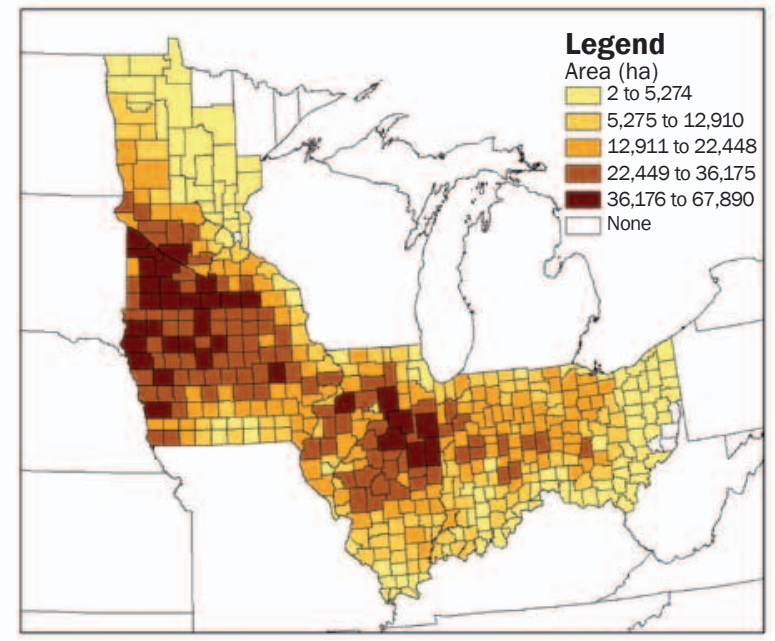

(c)

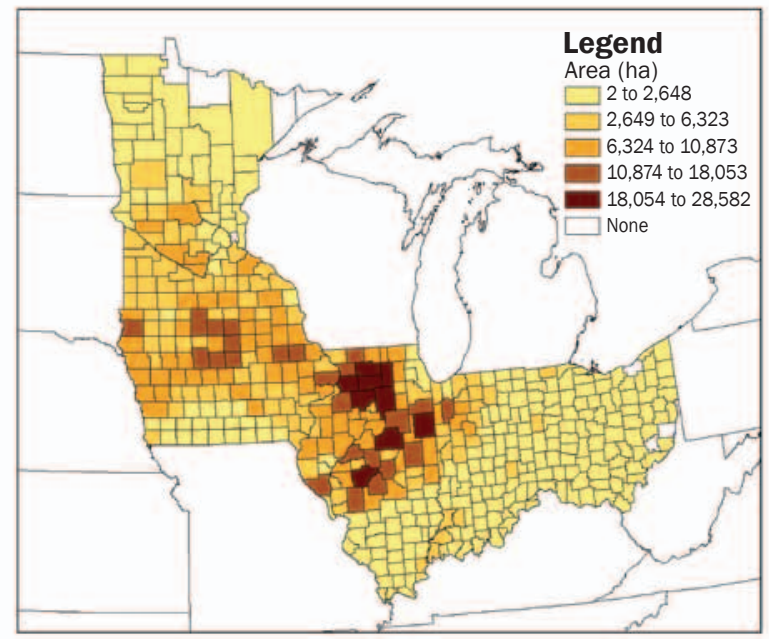

bean was either performed in the spring or could have been converted to spring tillage.

To examine the regional modeling results in more detail in terms of cropping and tillage systems, we applied the same two modeling scenarios to the $10 \mathrm{MRBI}$ watershed counties (table 4). Because the model simulations specify drained cropland and either the corn-soybean rotation or continuous corn, there is a substantial reduction in cropland considered by the model for reductions of $\mathrm{NO}_{3}$ loss by the cover crops relative to the potential for cover crops discussed previously for the 10 case study counties. For most of the counties, there were substantial areas of corn and soybean production that are not artificially drained, with five counties having less than $50 \%$ of the corn and soybean cropland drained. For all counties, there were small reductions in cropland included for scenario 2 compared with the total potential cropland because of corn or soybean following wheat or soybean following soybean. This was especially true for both counties in Ohio, which had both moderate amounts of wheat and second year soybean. As discussed earlier, a cereal rye cover crop on corn and soybean cropland without artificial drainage would probably reduce $\mathrm{NO}_{3}$ reaching surface waters, but the effect is likely to be less than that on land with drainage. Additionally, the reduction in $\mathrm{NO}_{3}$ loss on an area basis for the 10 counties illustrates the impact of climate and location on cover crop effectiveness and to some extent the prevalence of certain rotation and tillage combinations as they affect cover crop adoption. The relatively low effectiveness of cover crops in the two Minnesota counties compared with the two Indiana counties is mostly a function of the greater simulated cover crop growth in the Indiana counties, as was also shown by the modeling study of Feyereisen et al. (2013). Thus, using cover crops to reduce $\mathrm{NO}_{3}$ loads from MRBI watersheds will depend on how climate affects cover crop growth and how cropping and tillage systems affect cover crop adoption.

We summed the land area and the total annual reduction in $\mathrm{NO}_{3}$ lost in tile drainage for each of the five states for the two scenarios of rotation and tillage shown in figures $2 \mathrm{a}$ and $2 \mathrm{~b}$. We estimate that over 2.5 million ha (6.2 million ac) of drained land is currently in the corn-soybean rotation and no-till or ridge-till (scenario 1; table 5), would be immediately suitable for overseeding into the standing cash crop at maturity, and would 
Figure 2

Root Zone Water Quality Model-simulated reduction in nitrate $(\mathrm{kg} \mathrm{N})$ in artificially drained cropland for winter rye overseeded at corn-soybean maturity in (a) no-till corn-soybean rotations and in (b) corn-soybean or continuous corn rotations with no-till or spring tillage systems.

(a)

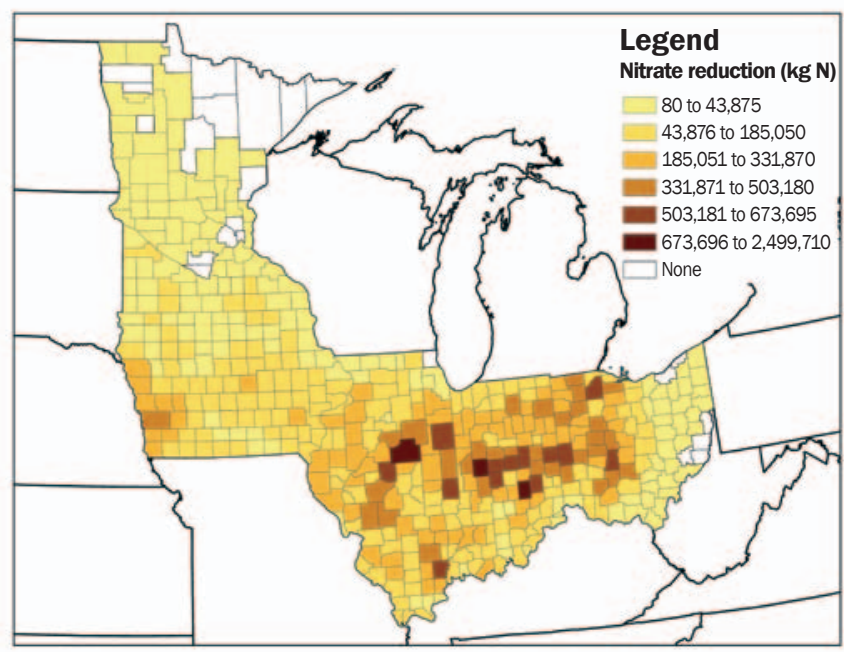

(b)

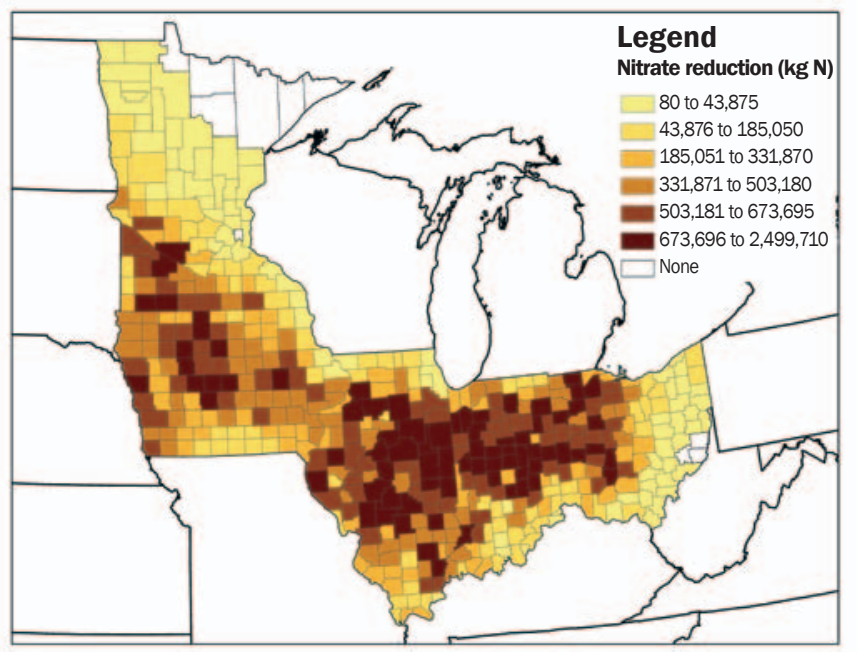

reduce $\mathrm{NO}_{3}$ loss in tile drainage by nearly 63 million $\mathrm{kg} \mathrm{N}$ (139 million $\mathrm{lb} \mathrm{N})$. When the continuous corn rotation and spring tillage were included (scenario 2; table 5), the simulated winter rye cover crop was grown on nearly 7.7 million ha (19 million ac) of artificially drained land in the five states and reduced annual $\mathrm{NO}_{3}$ losses by over 180 million $\mathrm{kg} \mathrm{N}$ (398 million $\mathrm{lb} \mathrm{N}$ ). If we include only the area within the five states that drains to the Mississippi River, we estimate an annual reduction of 153 million $\mathrm{kg} \mathrm{N}(314$ million $\mathrm{lb} \mathrm{N}$ ). For comparison this reduction equals $19 \%$ of the 813 million $\mathrm{kg} \mathrm{N}(1,792$ million $\mathrm{lb} \mathrm{N}$ ) transported to the Gulf of
Mexico each year by the Mississippi River (EPA Science Advisory Board 2007). Thus, the reduction in $\mathrm{NO}_{3}$ from adopting winter rye cover crop on only a portion of the land areas in corn and soybean production that is artificially drained in these five states represents almost $19 \%$ of the total load entering the Gulf of Mexico from the Mississippi River and driving hypoxia each year. This $19 \%$ total reduction can be compared to the $45 \%$ reduction called for in the latest Gulf Hypoxia Action Plan (MR GMWNTF 2008). Thus, state-wide adoption of winter rye cover crops on the drained row crop lands in just five states has the potential to meet a substantial portion of the required reduction in $\mathrm{NO}_{3}$ loading needed to reduce the size of the hypoxic zone in the Gulf to no more than the target of $5,000 \mathrm{~km}^{2}(1,930$ $\mathrm{mi}^{2}$ ) each year.

Costs. We estimated the cost of $\mathrm{NO}_{3}$ removal for winter rye to compare to other on- and off-field practices designed to reduce $\mathrm{N}$ losses. Singer et al. (2007) found that 56\% of farmers responding to a survey would plant a cover crop for a minimum payment of US $\$ 56.81 \mathrm{ha}^{-1}\left(\mathrm{US} \$ 23 \mathrm{ac}^{-1}\right)$ with a $95 \%$ confidence interval ranging from US $\$ 51.87$ to US $\$ 62.49 \mathrm{ha}^{-1}$ (US $\$ 21 \mathrm{ac}^{-1}$ to US $\$ 25.3$ $\left.\mathrm{ac}^{-1}\right)$. Using this $95 \%$ interval as an estimate of the cost for having cover crops planted, we can compute a cost per kilogram $\mathrm{N}$ of $\mathrm{NO}_{3}$ removed with cover crops. These are given in table 5, where costs range from US $\$ 2.24$ to US $\$ 3.25 \mathrm{~kg}^{-1} \mathrm{~N}$ (US $\$ 1.02 \mathrm{lb}^{-1}$ to US $\$ 1.48$ $\left.\mathrm{lb}^{-1}\right)$ removed depending on the different levels of cover crop adoption and their efficacy for removing $\mathrm{NO}_{3}$. This is a very competitive price range when compared to other management practices for reducing $\mathrm{NO}_{3}$ loads to surface waters, such as drainage water management (US $\$ 2.71 \mathrm{~kg}^{-1} \mathrm{~N}$ ), constructed wetlands (US\$3.26 kg-1 $\mathrm{N}$ ), and denitrification bioreactors (US\$2.39 to US $\$ 15.17$ $\mathrm{kg}^{-1} \mathrm{~N}$ ) (Schipper et al. 2010). Cover crops, however, are even more cost effective than their $\mathrm{NO}_{3}$ loss reduction potential indicates because this cost benefit does not take into account the substantial benefits for decreasing $\mathrm{P}$ and sediment losses from soil and for increasing soil organic matter (Kaspar and Singer 2011).

\section{Summary and Conclusions}

Our analysis focused on only five corn and soybean producing states in the Upper Midwest. These states have been estimated as the source on average of $46 \%$ of the $\mathrm{NO}_{3}-\mathrm{N}$ loadings to the Gulf of Mexico (Alexander et al. 2008). For cover crops to have a significant impact on $\mathrm{NO}_{3}$ losses in the Upper Midwest, they must be used in corn and soybean production fields, which are $75 \%$ to $95 \%$ of the cropland in these five states (NASS 2009). Simulations of fall-planted winter rye as a cover crop and no cover crop for climate conditions and common management practices across the midwestern United States demonstrate that a cover crop has potential to reduce $\mathrm{NO}_{3}$ loss to the Mississippi River by approximately $20 \%$. This simulated reduction is for winter rye 
Table 4

Cropland areas with potential for cover crops and Root Zone Water Quality Model simulated nitrate $\left(\mathrm{NO}_{3}\right)$ loss reduction under different scenarios for 10 midwestern counties.

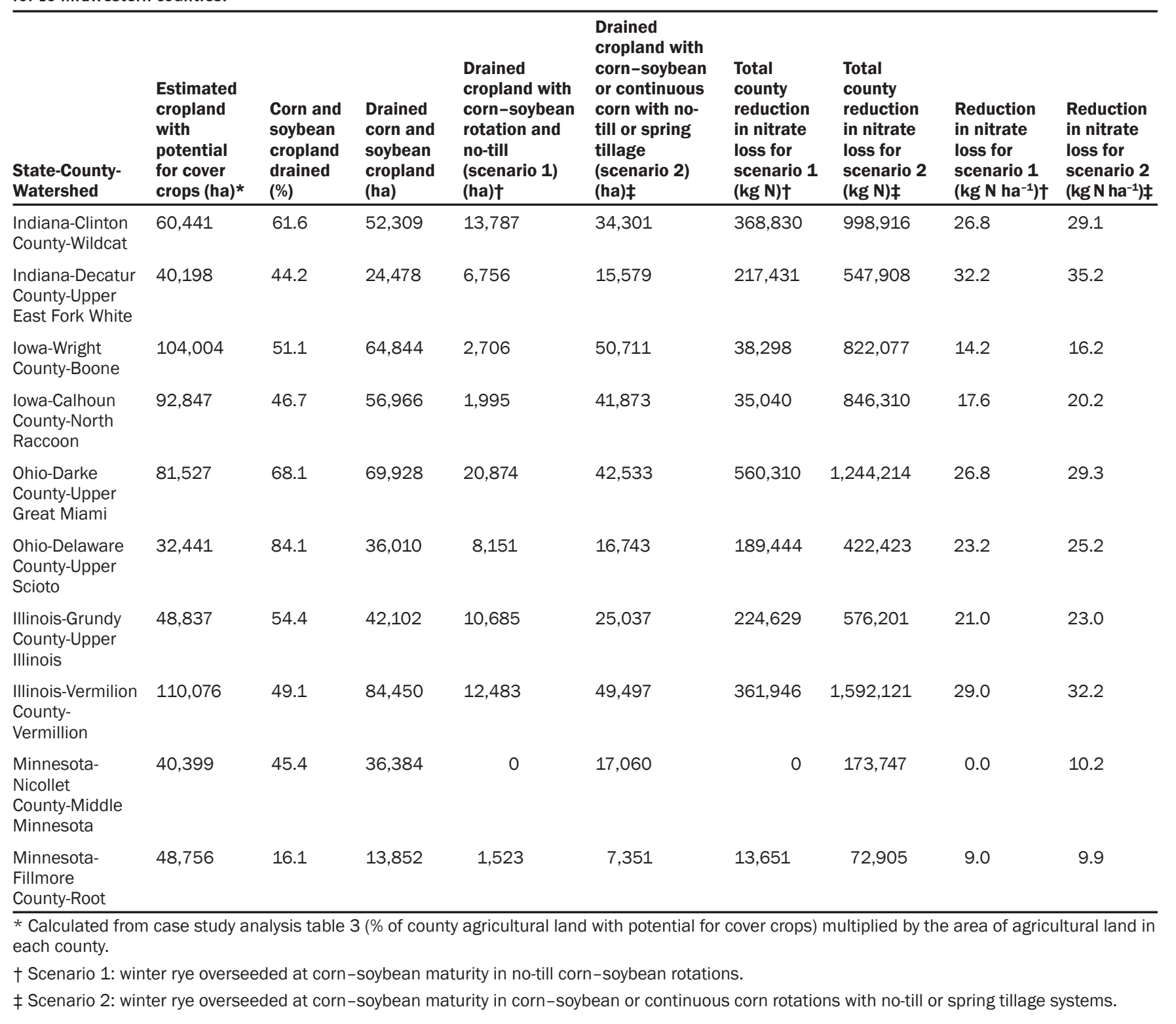

\section{Table 5}

Potential cover crop area planted for two scenarios, total nitrate loss reduction, and reduction in nitrogen (N) loss per land area for fall-planted winter rye as a cover crop in five midwestern states for various planting and tillage practices.

\begin{tabular}{|c|c|c|c|c|}
\hline Scenario & Area (ha) & $\begin{array}{l}\text { Total reduction in } \\
\mathrm{N} \text { loss (kg) }\end{array}$ & $\begin{array}{l}\text { Reduction in } \\
\mathrm{N} \text { loss per } \\
\text { land area }\left(\mathrm{kg} \mathrm{N} \mathrm{ha}^{-1}\right)\end{array}$ & $\begin{array}{l}\text { Cost } \\
\left.\text { (US\$ kg } \mathbf{~}^{-1} \mathbf{N}\right) \text { * }\end{array}$ \\
\hline $\begin{array}{l}\text { Drained cropland with corn-soybean } \\
\text { rotation and no-till }\end{array}$ & $2,534,000$ & $62,992,000$ & 24.9 & 2.24 to 3.08 \\
\hline $\begin{array}{l}\text { Drained cropland with corn-soybean and } \\
\text { continuous corn, no till and spring till }\end{array}$ & $7,662,000$ & $180,625,000$ & 23.6 & 2.36 to 3.25 \\
\hline
\end{tabular}


successfully established with overseeding at main crop maturity in continuous corn and corn-soybean systems on tile drained lands managed with no-till, spring-till, or fall-till that could be transitioned to spring tillage. The estimated adoption is somewhat optimistic in that conversion from fall tillage after corn to either spring tillage or no-till would be a difficult transition for many farmers. The assumption of successful overseeding is also optimistic because overseeding will not result in successful establishment in all years. On the other hand, the estimated reductions in $\mathrm{NO}_{3}$ leaching are somewhat conservative because they do not include corn or soybeans being grown on undrained land or grown in any sequence other than cornsoybean or continuous corn. Obviously, further research, development, and technical assistance are needed to overcome practical obstacles to cover crop adoption in this region. Additional field experiments also are needed to measure cover crop effects on $\mathrm{NO}_{3}$ losses in drainage water on multiple soil types across the region. These data can then be used to calibrate and validate RZWQM for additional soils and improve estimates of cover crop reductions of $\mathrm{NO}_{3}$ loss across the region. In any event, our analysis clearly shows that successful widespread use of winter cover crops across the Midwest would have substantial impacts on reducing $\mathrm{NO}_{3}$ loads to the Mississippi River.

\section{Acknowledgements}

The authors acknowledge helpful discussions with Barry Fisher from Indiana Natural Resource Conservation Service and Mark Hanna, Agriculture and Biosystems Engineering, Iowa State University in Ames, Iowa. This research was the result of an invited workshop held on October 21 to 22, 2010 at Princeton University that was sponsored by the Princeton Environmental Institute (PEI) and funded by a grant from the Walton Family Foundation.

\section{References}

Alexander, R.B., R.A. Smith, G.E. Schwarz, E.W. Boyer, J.V. Nolan, and J.W. Brakebill. 2008. Differences in phosphorus and nitrogen delivery to the Gulf of Mexico from the Mississippi River basin. Environmental Science and Technology 42:822-830.

Baker, J.M., and T.J. Griffis. 2009. Evaluating the potential use of winter cover crops in corn-soybean systems for sustainable co-production of food and fuel. Agricultural and Forest Meteorology 149:2120-2132.

Brandi-Dohrn, F.M., M. Hess, J.S. Selker, R.P. Dick, S.M. Kauffman, and D.D. Hemphill, Jr. 1997. Nitrate leaching under a cereal rye cover crop. Journal of Environmental Quality 26:181-188.

Burkart, M. R., and D. E. James. 1999. Agricultural-nitrogen contributions to hypoxia in the Gulf of Mexico. Journal of Environmental Quality 28:850-859.

Clark, A. 2007. Managing cover crops profitably. Beltsville, MD: Sustainable Agriculture Network.

CTIC (Conservation Technology Information Center). 2011. The National Crop Residue Management (CRM) Survey. http://www.conservationinformation. org/CRM/.

David, M.B., L.E. Drinkwater, and G.F. Mclsaac. 2010. Sources of nitrate yields in the Mississippi River basin. Journal of Environmental Quality 39:1657-1667.

EPA SAB (Environmental Protection Agency Science Advisory Board) . 2007. Hypoxia in the Northern Gulf of Mexico. An update by the EPA Science Advisory Board. EPA-SAB-08-003.

Feyereisen, G.W., G.G.T. Camargo, R.E. Baxter, J.M. Baker, and T.L. Richard. 2013. Cellulosic biofuel potential of a winter rye double crop across the U.S. corn-soybean belt. Agronomy Journal 105:631-642.

Feyereisen, G.W., B.N. Wilson, G.R. Sands, J.S. Strock, and P.M. Porter. 2006. Potential for a rye cover crop to reduce nitrate loss in southwestern Minnesota. Agronomy Journal 98:1416-1426.

Fisher, K.A., B. Momen, and R.J. Kratochvil. 2011. Is broadcasting seed an effective winter cover crop planting method? Agronomy Journal. 103:472-478.

Goolsby, D.A., W.A. Battaglin, B.T. Aulenbach, and R.P. Hooper. 2001. Nitrogen input to the Gulf of Mexico. Journal of Environmental Quality 30:329-336.

Jaynes, D.B., and D.E. James. 2007. The Extent of Farm Drainage in the United States. http://www. ars.usda.gov/SP2UserFiles/Place/36251500/ TheExtentofFarmDrainageintheUnitedStates.pdf.

Jones, R.J. 1942. Nitrogen losses from Alabama soils in lysimeters as influenced by various systems of green manure crop management. Agronomy Journal 34:574-585.

Kaspar, T.C., D.B. Jaynes, T.B. Parkin, and T.B. Moorman. 2007. Rye cover crop and gamagrass strip effects on $\mathrm{NO}_{3}$ concentration and load in tile drainage. Journal of Environmental Quality 36:1503-1511.

Kaspar,T.C., D.B. Jaynes, T.B. Parkin, T.B. Moorman, and J.W. Singer. 2012. Effectiveness of oat and rye cover crops in reducing nitrate losses in drainage water. Agricultural Water Management 110:25-33.

Kaspar, T.C., E.J. Kladivko, J.W. Singer, S. Morse, and D.R. Mutch. 2008. Potential and limitations of cover crops, living mulches, and perennials to reduce nutrient losses to water sources from agricultural fields in the Upper Mississippi River Basin. In Final Report: Gulf Hypoxia and Local Water Quality Concerns Workshop, 129-148, Ames, IA, Sept. 26-28, 2005. St. Joseph, MI: American Society of Agricultural and Biological Engineers.
Kaspar, T.C., and J.W. Singer. 2011. The use of cover crops to manage soil. In Soil management: Building a stable base for agriculture, eds. J.L. Hatfield and T.J. Sauer, 321-337. Madison, WI: American Society of Agronomy and Soil Science Society of America.

Kladivko, E.J., J.R. Frankenberger, D.B. Jaynes, D.W. Meek, B.J. Jenkinson, and N.R. Fausey. 2004. Nitrate leaching to subsurface drains as affected by drain spacing and changes in crop production system. Journal of Environmental Quality 33:1803-1813.

Li, L., R. W. Malone, L. Ma, T. C. Kaspar, D.B. Jaynes, S.A. Saseendran, K.R. Thorp, Q. Yu, and L.R. Ahuja. 2008. Winter cover crop effects on nitrate leaching in subsurface drainage as simulated by RZWQM-DSSAT. Transactions of the American Society of Agricultural and Biological Engineers 51:1575-1583.

Malone, R.W., D.B. Jaynes, T.C. Kaspar, K.R. Thorp, E. Kladivko, L. Ma, D.E. James, J. Singer, X. K. Morin, and T. Searchinger. 2014. Cover crops in the upper Midwest USA: simulated effect on nitrate leaching with artificial drainage. Journal of Soil and Water Conservation 69(4):292-305

McCracken, D.V., M.S. Smith, J.H. Grove, R.L. Blevins, and C.T. MacKown. 1994. Nitrate leaching as influenced by cover cropping and nitrogen source. Soil Science Society of America Journal 58:1476-1483.

Midwest Cover Crops Council. 2012. Midwest Cover Crops Field Guide. West Lafayette, IN: Purdue Extension. Purdue Extension Publication ID-433.

MRGMWNTF (Mississippi River/Gulf of Mexico Watershed Nutrient Task Force). 2008. Gulf Hypoxia Action Plan 2008 for Reducing, Mitigating, and Controlling Hypoxia in the Northern Gulf of Mexico and Improving Water Quality in the Mississippi River Basin. Washington, DC: Mississippi River/Gulf of Mexico Watershed Nutrient Task Force.

NASS (National Agriculture Statistics Service). 2011. CropScape - Cropland Data Layer. http://nassgeodata. gmu.edu/CropScape/.

NASS. 2009. 2007 Census of Agriculture. http://www. agcensus.usda.gov/Publications/2007/Full_Report/.

NRCS (Natural Resources Conservation Service). 2011. Natural Resources Conservation Service. National Resources Inventory. http://www.nrcs.usda.gov/wps/ portal $/ \mathrm{nrcs} / \mathrm{main} /$ ?ss $=16 \&$ navtype $=$ SubNavigation $\&$ cid=null\&navid=120110100000000\&pnavid = $120110000000000 \&$ position $=$ SubNavigation\&ttype $=$ main\&pname $=$ National $\% 20$ Resources $\% 20$ Inventory $\%$ $201 \% 20$ NRCS.

NRCS. 2012. Natural Resources Conservation Service, Mississippi River Basin Healthy Watersheds Initiative. http://www.nrcs.usda.gov/wps/portal/ nrcs/detailfull/national/programs/farmbill/ initiatives/?\&cid=nrcsdev11_024120.

Pavelis, G.A. 1987. Economic survey of farm drainage. In Farm drainage in the United States: History, status, and 
prospects, ed. G.A. Pavelis. USDA Misc. Publ. 1455 Washington, DC: US Government Print Office.

Rabalais, N.N,W.J.Wiseman, R. E.Turner, B. K. S. Gupta, and Q. Dortch. 1996. Nutrient changes in the Mississippi River and system responses on the adjacent continental shelf. Estuaries and Coasts 19:386-407.

Rasse, D.P., J.T. Ritchie, W.R. Peterson, J. Wei, and A.J.M. Smucker. 2000. Rye cover crop and nitrogen fertilization effects on nitrate leaching in inbred maize fields. Journal of Environmental Quality 29:298-304.

Ritter, W.F., R.W. Scarborough, and A.E.M. Chirnside. 1998. Winter cover crops as a best management practice for reducing nitrogen leaching. Journal of Contaminant Hydrology. 34:1-15.

Robertson, D.M., G.E. Schwarz, D.A. Saad, and R.B. Alexander. 2009. Incorporating uncertainty into the ranking of SPARROW model nutrient yields from Mississippi-Atchafalaya River basin watersheds. Journal of the American Water Resources Association 45:534-549.

Royer, T.V., M.B. David, and L.E. Gentry. 2006. Timing of riverine export of nitrate and phosphorus from agricultural watersheds in Illinois: Implications for reducing nutrient loading to the Mississippi River. Environmental Science and Technology 40:4126-4131.

Schilling, K.E., M.D. Tomer, Y.K. Zhang, T. Weisbrod, P. Jacobson, and C.A. Cambardella. 2007. Hydrogeologic controls on nitrate transport in a small agricultural catchment, Iowa. Journal of Geophysical Research-Biogeosciences 112, G03007, doi: 10.1029/2007JG000405.

Schipper, L.A., W.D. Robertson, A.J. Gold, D.B. Jaynes, and S.C. Cameron. 2010. Denitrifying bioreactors-An approach for reducing nitrate loads to receiving waters. Ecological Engineering 36:1532-1543.

Singer, J.W. 2008. Corn Belt assessment of cover crop management and preferences. Agronomy Journal 100:1670-1672.

Singer, J.W., S.M. Nusser, and C.J. Alf. 2007. Are cover crops being used in the U.S. Corn Belt? Journal of Soil and Water Conservation 62(5):353-358.

Soil Survey Staff. 2012. U.S. General Soil Map (STATSGO2). Natural Resources Conservation Service, United States Department of Agriculture. http://soildatamart.nrcs.usda.gov.

Staver, K.W., and R.B. Brinsfield. 1990. Patterns of soil nitrate availability in corn production systems - implications for reducing groundwater contamination. Journal of Soil and Water Conservation 45(2):318-323.

Staver, K.W., and R.B. Brinsfield. 1998. Using cereal grain winter cover crops to reduce groundwater nitrate contamination in the mid-Atlantic coastal plain. Journal of Soil and Water Conservation 53(3):230-240.

Strock, J.S., P.M. Porter, and M.P. Russelle. 2004. Cover cropping to reduce nitrate loss through subsurface drainage in the northern U.S. Corn Belt. Journal of Environmental Quality 33:1010-1016.
Thorp, K.R., D.B. Jaynes, and R.W. Malone. 2008 Simulating the long-term performance of drainage water management across the Midwestern United States. Transactions of the American Society of Agricultural and Biological Engineers 51:961-976.

Tomer, M.D., and M.R. Burkart. 2003. Long-term effects of nitrogen fertilizer use on ground water nitrate in two small watersheds. Journal of Environmental Quality 32:2158-2171.

Tonitto, C., M.B. David, and L.E. Drinkwater. 2006 Replacing bare fallows with cover crops in fertilizerintensive cropping systems: A meta-analysis of crop yield and $\mathrm{N}$ dynamics. Agricultural Ecosystems and Environment 112:58-72.

Vetsch, J.A., G.W. Randall, and J.A. Lamb. 2007. Corn and soybean production as affected by tillage systems. Agronomy Journal 99:952-959.

Wilson, M.L., J.M. Baker, and D.L. Allan. 2013. Factors affecting successful establishment of aerially seeded winter rye. Agronomy Journal 105, doi 10.2134/ agronj2013.0133.

Wyland, L.J., L.E. Jackson, W.E. Chaney, K. Klonsky, S.T. Koike, and B. Kimple. 1996. Winter cover crops in a vegetable cropping system: Impacts on nitrate leaching, soil water, crop yield, pests and management costs. Agricultural Ecosystems and Environment 59:1-17.

USGS (US Geological Survey). 2011. National Land Cover Dataset 1992 (NLCD 1992). http://landcover.usgs.gov/ natllandcover.php.

Zucker, L.A., and L.C. Brown 1998. Agricultural drainage: Water quality impacts and subsurface drainage studies in the Midwest. Columbus, $\mathrm{OH}$ : Ohio State University Extension. Bulletin 871 